\title{
Pengembangan perangkat pembelajaran matematika menggunakan pendekatan inquiry berorientasi kemampuan berpikir kritis
}

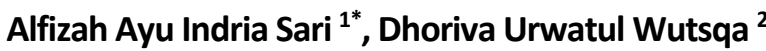 \\ ${ }^{1}$ Sekolah Tinggi Ekonomi Syariah (STES) Manna wa Salwa, Indonesia \\ 2 Department of Mathematics Education, Universitas Negeri Yogyakarta, Indonesia \\ *Corresponding Author. E-mail: alfayundria@gmail.com
}

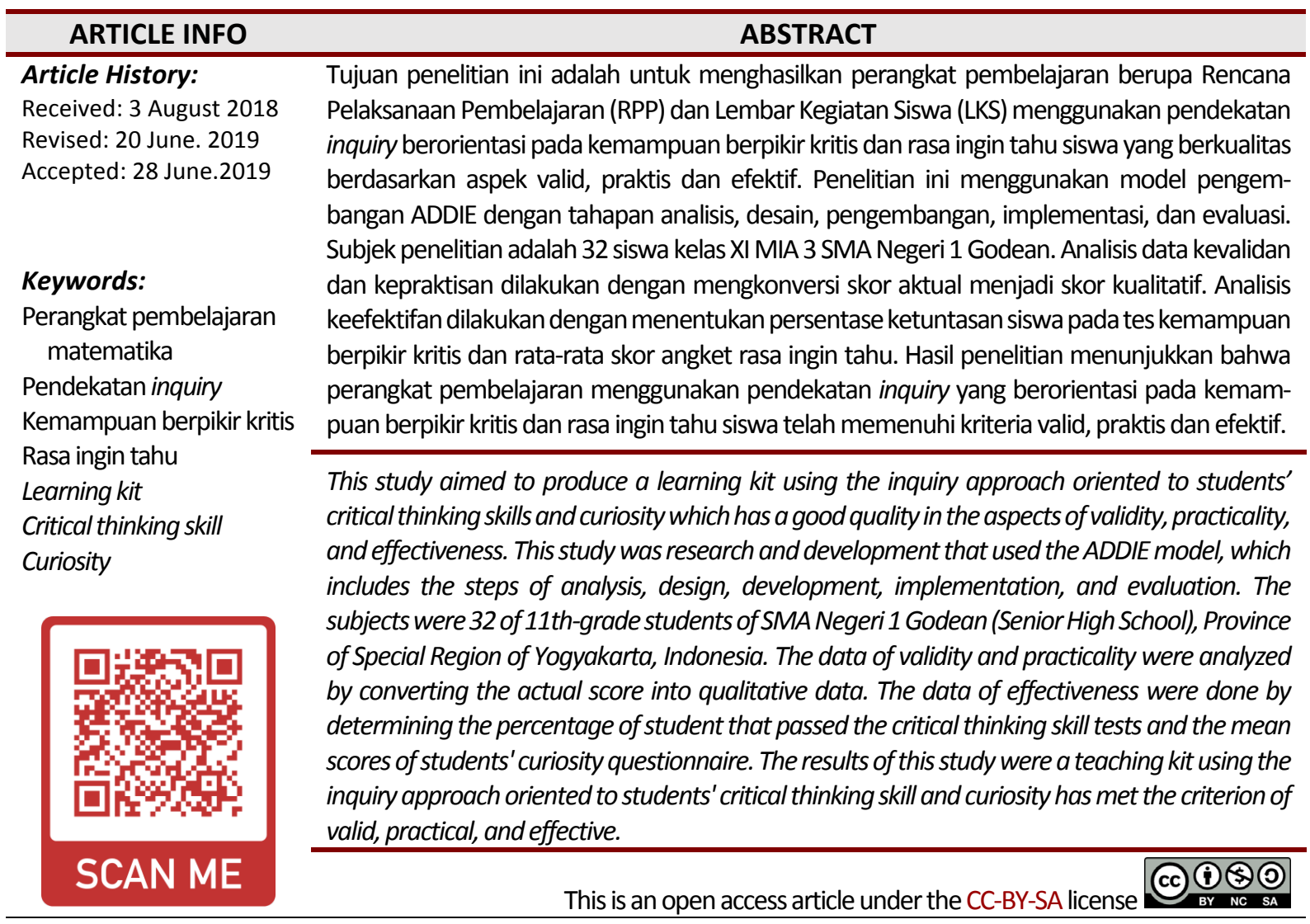

How to Cite:

Sari, A. A. I., \& Wutsqa, D. U. (2019). Pengembangan perangkat pembelajaran matematika menggunakan pendekatan inquiry berorientasi kemampuan berpikir kritis. PYTHAGORAS: Jurnal Pendidikan Matematika, 14(1), 56-71. doi: https://doi.org/10.21831/pg.v14i1.27303 


\section{PENDAHULUAN}

Matematika merupakan pelajaran yang wajib diberikan pada setiap jenjang pendidikan mulai dari sekolah dasar hingga sekolah menengah atas. Melalui pelajaran matematika, diharapkan siswa mampu tumbuh dan berkembang menjadi pribadi yang siap menggunakan matematika dalam menjawab berbagai tantangan kehidupan sekarang maupun di masa yang akan datang. Hal ini sesuai dengan pendapat Lawrence (Chambers, 2008, p.9) yang menyatakan matematika itu mempelajari tentang pola-pola yang abstrak dari dunia sekitar kita dan dapat diaplikasikan pada banyak disiplin ilmu seperti seni, ilmu alam, keuangan, kesehatan dan ilmu sosial. Sehingga dapat dipahami bahwa pelajaran matematika memiliki keterkaitan dengan bidang lain dan berperan penting dalam kehidupan.

Permendikbud Nomor 59 tahun 2014 tentang Kurikulum SMA/MA menyatakan bahwa pelajaran matematika perlu diberikan kepada semua peserta didik untuk membekali mereka dengan kemampuan berpikir logis, analitis, sistematis, kritis, inovatif, dan kreatif serta kemampuan bekerja sama. Terkait dengan tujuan tersebut, maka dalam melaksanakan pembelajaran matematika penting untuk dikembangkan berbagai kemampuan, salah satunya kemampuan berpikir kritis (Kemendikbud, 2014a). Hal ini sejalan dengan pendapat Aizikovitsh dan Cheng (2015, p.455) yang mengungkapkan bahwa kemampuan berpikir kritis penting untuk dikembangkan dalam pembelajaran matematika.

Menurut Conklin (2012, p.14) berpikir kritis merupakan salah satu bagian dari kemampuan berpikir tingkat tinggi. Freeley (2001, p.2) mendefinisikan berpikir kritis sebagai "the ability to analyze, criticize, and advocate ideas; to reason inductively and deductively; and to reach factual or judgemental conclusions based on sound inferences drawn from unambiguous statements of knowledge or belief". Siswa yang mampu berpikir kritis dapat mengevaluasi pikirannya dan membandingkannya dengan fakta atau pemikiran orang lain. Hal ini diperkuat dengan pernyataan Bayer (1990, p.57) yang menyatakan bahwa berpikir kritis meliputi kemampuan untuk menentukan kredibilitas sumber; membedakan antara yang relevan dan yang tidak; membedakan fakta dari penilaian; mengidentifikasi dan mengevaluasi asumsi implisit; mengidentifikasi bias yang ada; mengidentifikasi sudut pandang dan mengevaluasi bukti yang ditawarkan untuk mendukung pengakuan.

Menurut Asgharheidari dan Tahriri (2015, p.388), berpikir kritis merupakan masalah penting dalam pendidikan modern. Pentingnya berpikir kritis juga dikemukakan oleh Firdaus, Kailani, Bakar, dan Bakry (2015, p.227) yang menyebutkan bahwa kemampuan berpikir kritis harus diterapkan dan dikembangkan dalam kurikulum dan proses pembelajaran untuk menghasilkan siswa yang memiliki kualitas berpikir tingkat tinggi. Meskipun kemampuan berpikir kritis sangat penting, namun kondisi di lapangan menunjukkan hal yang berbeda. Firdaus et al. (2015, p.227) menyatakan bahwa sistem pembelajaran di Indonesia masih mengabaikan pengembangan kemampuan berpikir kritis siswa. Hal ini semakin dipertegas oleh Fatmawati, Mardiyana, dan Triyanto (2014, p.912) bahwa pembelajaran matematika di sekolah umumnya masih menggunakan metode ceramah sehingga ke-mampuan berpikir kritis siswa sangat sulit untuk dikembangkan.

Thompson (2011, p.1) menyebutkan bahwa hasil pembelajaran untuk mengembangkan kemampuan berpikir kritis belum dapat tercapai secara optimal. Sejalan dengan hal itu menurut Damanik dan Bukit (2013, p.17) dua faktor penyebab tidak berkembangnya kemampuan berpikir kritis selama ini adalah kurikulum yang umumnya dirancang dengan target materi yang luas sehingga pengajar lebih terfokus pada penyelesaian materi dan kurangnya pemahaman mengajar tentang model pembelajaran yang dapat meningkatkan kemampuan berpikir kritis. Selain itu, berdasarkan hasil pretest yang telah dilakukan di SMA Negeri 1 Godean, diperoleh data bahwa kemampuan berpikir siswa masih rendah. Hasil tersebut berdasarkan fakta bahwa dari 32 orang siswa, 10 siswa memperoleh skor empat, sedangkan 19 siswa memperoleh skor enam, 2 siswa memperoleh skor 10 dan hanya satu siswa memperoleh skor 13 dari skor maksimum 15 . Hasil tersebut menunjukkan perlu adanya perbaikan pada kemampuan berpikir kritis siswa.

Selain aspek kognitif, aspek lain yang perlu diperhatikan adalah aspek sikap, salah satunya adalah rasa ingin tahu siswa. Menurut Renner (2006, p.305), "curiosity has been conceptualized as desire for new information and knowledge". Sedangkan menurut McElmeel $(2002$, p.51) rasa ingin tahu adalah keinginan untuk belajar, menyelidiki atau mengetahui dan mengarah ke aktivitas eksplorasi (exploration) atau penyelidikan (inquiry). Rasa ingin tahu harus dimiliki oleh siswa dalam belajar. Maw dan Maw (1963, p.77) menyatakan bahwa siswa dengan tingkat rasa ingin tahu tinggi akan lebih mudah mendapat informasi daripada siswa dengan tingkat rasa ingin tahu rendah. Hal ini menunjukkan bahwa rasa ingin tahu penting untuk dimiliki oleh siswa dalam kegiatan belajar. 
Kemampuan berpikir kritis erat kaitannya dengan rasa ingin tahu. Menurut Facione (1990, p.99) salah satu ciri seseorang yang memiliki kemampuan berpikir kritis ditandai dengan adanya rasa ingin tahu dalam mengeksplorasi persoalan dan mencari informasi. Selain itu, Bundu (2006, p.141) juga menyatakan bahwa rasa ingin tahu mendorong siswa dalam penemuan sesuatu yang baru, salah satunya melalui kemampuan berpikir kritis. Hal ini mengindikasi bahwa rasa ingin tahu memiliki pengaruh yang cukup besar dalam menjembatani siswa untuk belajar, terutama dalam membantu meningkatkan kemampuan berpikir kritis siswa.

Namun faktanya masih banyak siswa yang memiliki rasa ingin tahu yang masih rendah. Rendahnya rasa ingin tahu menurut Damanik dan Bukit $(2013$, p.18) dapat ditunjukkan dengan fakta bahwa hanya sebagian kecil siswa yang mengajukan pertanyaan pada saat proses pembelajaran berlangsung. Astika, Suma, dan Suastra $(2013$, p.3) juga menyatakan bahwa salah satu faktor rendahnya kemampuan berpikir kritis siswa dapat dilihat dari rasa ingin tahu siswa dalam mencari informasi masih rendah. Siswa cenderung pasif dan guru yang hanya memberikan informasi. Selain itu, berdasarkan hasil wawancara dengan salah satu guru di salah satu SMA negeri di Kabupaten Bantul, Provinsi Daerah Istimewa Yogyakarta, diperoleh data bahwa dalam kegiatan pembelajaran siswa masih cenderung belum berpartisipasi aktif. Siswa cenderung masih menjadikan guru sebagai satu-satunya sumber dalam belajar. Siswa masih pasif dalam mencari informasi yang berkaitan dengan pembelajaran. Keinginan untuk memperoleh pengetahuan baru dan berusaha mempelajari sesuatu masih rendah. Hal tersebut mengindikasikan bahwa rasa ingin tahu siswa masih rendah.

Berdasarkan uraian tersebut, permasalahan yang muncul adalah bagaimana guru mampu merencanakan kegiatan pembelajaran matematika sehingga dapat membantu siswa dalam mencapai hasil belajar yang baik. Sesuai dengan pendapat Kunandar (2013, p.62) yang menyatakan bahwa hasil belajar adalah kompetensi atau kemampuan tertentu baik kognitif, afektif maupun psikomotorik yang dicapai atau dikuasai siswa setelah mengikuti proses belajar mengajar. Termasuk di dalamnya kemampuan berpikir kritis dan rasa ingin tahu siswa.

Guru memiliki peranan penting dalam pencapaian tujuan pendidikan. Diharapkan guru dapat merencanakan dan melaksanakan proses pembelajaran yang efektif sehingga tujuan pembelajaran tercapai. Hal ini sesuai dengan pendapat Moon, Mayes, dan Hutchinson (2002, p.54) yang menyatakan bahwa guru yang efektif adalah guru yang mempunyai persiapan dan pelaksanaan pembelajaran yang sistematis. Selain itu menurut Permendikbud Nomor 65 Tahun 2013 tentang Standar Proses disebutkan bahwa setiap guru pada satuan pendidikan berkewajiban menyusun RPP secara lengkap dan sistematis agar pembelajaran berlangsung secara interaktif, inspiratif, menyenangkan, menantang, memotivasi peserta didik untuk berpartisipasi aktif serta memberi ruang yang cukup bagi prakarsa, kreativitas dan kemandirian sesuai dengan bakat, minat dan perkembangan fisik serta psikologis peserta didik (Kemendikbud, 2013).

Berdasarkan hasil telaah yang dilakukan oleh Suhartini dan Santoso $(2014$, p.70) diperoleh keterangan bahwa masih sedikit guru yang mengembangkan perangkat pembelajaran secara mandiri. Lebih lanjut menurut Sumarno dan Wutsqa (2014, p.258), sebagian besar guru belum mengembangkan RPP dan LKS sebagai bagian dari perangkat pembelajaran. Pendapat tersebut diperkuat dari hasil survei awal dan wawancara yang dilakukan dengan beberapa guru Matematika SMA. Dari delapan orang guru yang diminta mengisi angket, enam orang menyatakan menyusun RPP dengan mengunduh dari internet dan hanya dua guru yang menyusun RPP sendiri. Selain itu dari hasil wawancara diketahui bahwa LKS yang digunakan dalam pembelajaran matematika pada umumnya dibeli dari penerbit. Hasil tersebut menunjukkan bahwa sebagian besar guru matematika belum mengembangkan perangkat pembelajaran yang sesuai dengan kebutuhan siswanya. Perangkat pembelajaran yang dibuat sering kali hanya sebagai tuntutan dan formalitas dalam kegiatan pembelajaran dan bukan sebagai kebutuhan untuk memfasilitasi kegiatan belajar siswa.

Fakta lain yang ditemukan dari hasil observasi dan angket, terdapat empat orang dari delapan guru yang masih menerapkan metode pembelajaran ceramah. Beberapa komentar guru mengatakan bahwa metode ceramah lebih mudah dilakukan. Hal ini menunjukkan bahwa proses pembelajaran masih bersifat berpusat pada guru. Guru jarang menggunakan model-model pembelajaran yang inovatif sehingga dalam kegiatan pembelajaran siswa cenderung pasif karena hanya menerima materi dari guru saja. Proses pembelajaran sebaiknya dapat memberikan ruang lebih kepada siswa dalam membangun pengetahuannya.

Pembelajaran matematika memerlukan suatu pendekatan yang dapat digunakan agar pembelajaran dapat bermakna bagi siswa. Terdapat banyak model atau pendekatan pembelajaran yang dapat digunakan dalam pembelajaran di kelas. Berdasarkan Permendikbud Nomor 65 Tahun 2013 tentang Standar Proses (Kemendikbud, 2013), disebutkan bahwa perlu diterapkan pembelajaran berbasis penyingkapan atau penelitian yaitu inquiry 
learning. Menurut Kuhlthau, Maniotes, dan Caspari (2007, p.2), inquiry is an approach to learning where by students find and use a variety of sources of information and ideas to increase their understanding of a problem, topic or issue. Pembelajaran dengan pendekatan inquiry tidak hanya melibatkan aktivitas percobaan saja namun juga merupakan kegiatan berpikir. Pendekatan inquiry menempatkan siswa sebagai subjek belajar yang berusaha mengembangkan cara berpikir ilmiah dan mengembangan keaktifan dalam memecahkan masalah (Sagala, 2011, p.196). Peningkatan keterampilan berpikir inilah yang menjadi salah satu tujuan pembelajaran dengan pendekatan inquiry.

Menurut Hester (Llewellyn, 2005, pp.2-3) dalam pembelajaran menggunakan pendekatan inquiry melibatkan proses berpikir kritis seperti metode diagnosis, spekulasi dan pengujian hipotesis. Pendekatan inquiry memberikan kesempatan pada siswa dalam menghadapi masalah, menghasilkan dan menguji ide. Perhatian utama terletak pada cara menguji dan menjelaskan informasi (peristiwa, fakta, situasi, perilaku, dan sebagainya). Hal ini diperkuat dengan pendapat Abdi $(2014$, p.37) yang menyebutkan bahwa dalam inquiry siswa ikut serta dalam banyak aktivitas yang dapat membangun pengetahuan baru. Minner, Levy, dan Century $(2009$, p.3) juga menambahkan bahwa pembelajaran inquiry lebih menekankan pada aktivitas investigasi menggunakan metode ilmiah, aktif dalam melakukan penyelidikan melalui aktivitas berpikir berdasarkan fenomena atau masalah. Selain itu melalui strategi pembelajaran inquiry menurut Anggareni, Ristiati, dan Widiyanti (2013, p.3) akan memberikan kesempatan kepada siswa untuk menemukan sendiri pengetahuannya serta berperan aktif dalam pembelajaran dan mengembangkan kemampuan berpikir kritisnya. Sehingga siswa akan lebih aktif dalam proses belajar karena sifat pembelajarannya yang berpusat pada siswa.

Menurut Borosi (Jarrett, 1997, p.12) terdapat beberapa strategi yang perlu diperhatikan dalam menciptakan lingkungan yang kondusif untuk memulai pembelajaran dengan pendekatan inquiry, yaitu: (1) gunakan masalah kehidupan nyata yang kompleks; (2) fokus pada topik matematika non-tradisional dimana ketidakpastian dan keterbatasan yang paling jelas; (3) gunakan kesalahan sebagai batu loncatan untuk kegiatan penyelidikan; (4) buat ketidakjelasan dan konflik yang memaksa siswa bertanya sehingga mendorong siswa untuk mengejar pertanyaan tersebut dan memiliki rasa pentingnya hasil penyelidikan; (5) bangkitkan kegiatan membaca untuk membaca untuk mendukung penyelidikan dan untuk mengajar siswa menggunakan sumber-sumber informasi selain guru sehingga membantu membuat siswa menjadi mandiri, memecahkan masalah dan berpikir kritis; (6) berikan kesempatan kepada siswa untuk merefleksi pentingnya penyelidikan; (7) promosikan dengan menukarkan hasil penyelidikan antar siswa.

Chiappetta dan Collate (1994, p.86) menyatakan bahwa pembelajaran dengan pendekatan inquiry melibatkan proses identifikasi masalah, menyampaikan pertanyaan dan mencari jawaban. Hal tersebut dapat dilakukan dengan cara observasi, melakukan prediksi, memanipulasi variabel, analisis situasi dan melakukan evaluasi. Dalam hal ini, langkah pembelajaran inquiry dapat memfasilitasi siswa dalam mengembangkan kemampuan berpikir kritisnya melalui aktivitas mengindentifikasi masalah, merumuskan pertanyaan dan melakukan penyelidikan. Keterkaitan antara pembelajaran dengan pendekatan inquiry dan rasa ingin tahu dijelaskan oleh pendapat McElmeel $(2002$, p.51) yang mengungkapkan bahwa pembelajaran inquiry diawali oleh rasa ingin tahu untuk melakukan penyelidikan dalam mencari penyelesaian dari suatu permasalahan. Llewellyn (2005, p.24) menyatakan bahwa di dalam inquiry melibatkan kemampuan berpikir kritis untuk memecahkan permasalahan yang dihadapinya. Selain itu menurut Abdi (2014, p.53), pembelajaran berbasis inquiry juga meningkatkan prestasi siswa, sehingga dengan menerapkan pendekatan inquiry diharapkan dapat mengasah kemampuan berpikir kritis siswa dan meningkatkan prestasi siswa.

Berdasarkan permasalahan yang telah disebutkan, perlu adanya pengembangan perangkat pembelajaran matematika yang berorientasi pada kemampuan berpikir kritis dan rasa ingin tahu siswa. Salah satu pendekatan yang dapat digunakan untuk meningkatkan kemampuan berpikir kritis dan rasa ingin tahu siswa adalah pendekatan inquiry. Dengan demikian, penelitian ini bertujuan untuk menghasilkan perangkat pembelajaran matematika SMA kelas XI semester genap menggunakan pendekatan inquiry berorientasi pada kemampuan berpikir kritis dan rasa ingin tahu siswa yang berkualitas.

\section{METODE}

Jenis penelitian yang digunakan dalam penelitian ini adalah penelitian pengembangan. Model penelitian pengembangan yang digunakan dalam penelitian ini adalah model ADDIE. Langkah-langkah model pengembangan ADDIE terdiri dari analysis (analisis), design (desain), development (pengembangan), implementation 
(implementasi), dan evaluation (evaluasi). Penelitian ini dilakukan pada bulan Maret sampai dengan Mei 2016. Adapun yang dijadikan sebagai tempat penelitian yaitu SMA Negeri 1 Godean, Yogyakarta. Subjek dalam penelitian ini terdiri dari 32 siswa kelas XI MIA 3 SMA Negeri 1 Godean.

Prosedur penelitian terdiri dari tahapan: (1) tahap analisis merupakan tahap para perencanaan pengembangan produk. Tahap analisis meliputi analisis kebutuhan, analisis karakteristik siswa, dan analisis materi. Analisis kebutuhan bertujuan untuk mengetahui masalah-masalah yang dihadapi dalam pembelajaran matematika, sehingga dibutuhkan pengembangan perangkat pembelajaran. Analisis siswa dilakukan untuk mengidentifikasi karakteristik siswa sesuai dengan jenjang pendidikannya serta untuk mengetahui perangkat pembelajaran yang sesuai sehingga dapat membantu siswa dalam proses pembelajaran. Analisis materi digunakan untuk menentukan materi yang digunakan dalam penelitian berdasarkan Kompetensi Inti (KI) dan Kompetensi Dasar (KD) pembelajaran sesuai dengan Kurikulum 2013; (2) tahap perencanaan (design) meliputi penyusunan Rencana Pelaksanaan Pembelajaran (RPP) dan Lembar Kegiatan Siswa (LKS) menggunakan pendekatan inquiry; (3) tahap pengembangan (development) dilakukan validasi ahli dan revisi produk; (4) tahap implementasi adalah tahap mengujicobakan perangkat pembelajaran dengan pendekatan inquiry; (5) tahap evaluasi yang akan dilakukan berdasarkan hasil uji coba perangkat pembelajaran, dimana pada tahap evaluasi dilakukan analisis kepraktisan dan keefektifan perangkat pembelajaran.

Data dalam penelitian ini diperoleh langsung oleh peneliti, sehingga data penelitian ini merupakan data primer. Terdapat dua macam data yang akan diperoleh dalam penelitian ini yaitu data kualitatif dan data kuantitatif. Data kualitatif merupakan data deskriptif selama proses pengembangan dan data kuantitatif merupakan data yang digunakan untuk mendapatkan nilai kevalidan, kepraktisan dan data keefektifan perangkat pembelajaran. Instrumen pengumpulan data terdiri dari instrumen untuk mengukur kevalidan, kepraktisan dan keefektifan. Instrumen untuk mengukur kevalidan menggunakan lembar validasi. Instrumen untuk mengukur kepraktisan menggunakan lembar observasi keterlaksanaan pembelajaran, lembar penilaian guru, dan lembar penilaian siswa. Instrumen untuk mengukur keefektifan menggunakan tes kemampuan berpikir kritis dan angket rasa ingin tahu siswa.

Teknik analisis data dilakukan untuk mendapatkan perangkat pembelajaran dengan pendekatan inquiry yang berkualitas yang memenuhi aspek kevalidan, kepraktisan, dan keefektifan. Pada analisis data kevalidan dan kepraktisan, data kuantitatif yang diperoleh diubah menjadi data kualitatif dengan skala lima. Pengubahan skor menjadi skala lima disajikan pada Tabel 1 (Widoyoko, 2009:238).

Tabel 1. Konversi Data Kuantitatif ke Kualitatif

\begin{tabular}{ll}
\hline Interval Skor & Kategori \\
\hline$X>\bar{X}_{i}+1,8 \mathrm{Sbi}$ & Sangat Baik \\
$\bar{X}_{i}+0,6 \mathrm{Sbi}<X \leq \bar{X}_{i}+1,8 \mathrm{Sbi}$ & Baik \\
$\bar{X}_{i}-0,6 \mathrm{Sbi}<X \leq \bar{X}_{i}+0,6 \mathrm{Sbi}$ & Cukup \\
$\bar{X}_{i}-1,8 \mathrm{Sbi}<X \leq \bar{X}_{i}-0,6 \mathrm{Sbi}$ & Kurang \\
$X \leq \bar{X}_{i}-1,8 \mathrm{Sbi}$ & Sangat Kurang \\
\hline
\end{tabular}

Keterangan :

$X \quad=$ skor empiris

$\bar{X}_{i}=$ rata-rata ideal $=\frac{1}{2}$ (skor maksimum ideal + skor minimum ideal $)$

Sbi $=\frac{1}{6}$ (skor maksimum ideal - skor minimum ideal)

Pada lembar validasi RPP terdapat 39 butir aspek yang dinilai, dengan skor tertinggi untuk masing-masing aspek adalah 5 dan skor terendah adalah 1 . Dengan menggunakan rumus konversi pada Tabel 1 diperoleh kategori skor penilaian kevalidan RPP seperti pada Tabel 2. Kualitas RPP dikatakan valid jika rata-rata penilaian minimal berada pada kategori baik. Pada lembar validasi LKS terdapat 30 butir aspek yang dinilai, dengan skor tertinggi untuk masing-masing aspek adalah 5 dan skor terendah adalah 1. Dengan menggunakan rumus konversi pada Tabel 1 diperoleh kategori skor penilaian kevalidan LKS seperti pada Tabel 3. Kualitas LKS dikatakan valid jika ratarata penilaian minimal berada pada kategori baik. Secara umum, perangkat pembelajaran yang dikembangkan dikatakan valid jika hasil penilaian RPP dan LKS berada pada kategori minimal baik. 
PYTHAGORAS: Jurnal Pendidikan Matematika, 14 (1), 2019 - 61

Alfizah Ayu Indria Sari, Dhoriva Urwatul Wutsqa

Tabel 2. Kategori Skor Penilaian Kevalidan RPP

\begin{tabular}{ll}
\hline Interval Skor & Kategori \\
\hline$X>163,8$ & Sangat Baik \\
$132,6<X \leq 163,8$ & Baik \\
$101,4<X \leq 132,6$ & Cukup \\
$70,2<X \leq 101,4$ & Kurang \\
$X \leq 70,2$ & Sangat Kurang \\
\hline \multicolumn{2}{c}{ Tabel 3.Kategori Skor Penilaian Kevalidan LKS } \\
\hline Interval Skor & Kategori \\
\hline$X>126$ & Sangat Baik \\
$102<X \leq 126$ & Baik \\
$78<X \leq 102$ & Cukup \\
$54<X \leq 78$ & Kurang \\
$X \leq 54$ & Sangat Kurang \\
\hline
\end{tabular}

Analisis kepraktisan perangkat pembelajaran terdiri dari lembar observasi keterlaksanaan pembelajaran, lembar penilaian guru, dan lembar penilaian siswa. Analisis data observasi keterlaksanaan pembelajaran yaitu dengan menghitung persentase keterlaksanaan aktivitas $(p)$ pada setiap pertemuan menggunakan rumus:

$$
p=\frac{\text { skor perolehan }}{\text { skor maksimal }} \times 100 \%
$$

Perangkat pembelajaran memenuhi kriteria praktis jika persentase $p \geq 90 \%$. Pada lembar penilaian kepraktisan oleh guru terdapat 17 butir aspek yang dinilai, dengan skor tertinggi untuk masing-masing aspek adalah 5 dan skor terendah adalah 1. Dengan menggunakan rumus konversi pada Tabel 1 diperoleh kategori skor penilaian kepraktisan oleh guru seperti pada Tabel 4.

Tabel 4. Kategori Skor Penilaian Kepraktisan oleh Guru

\begin{tabular}{ll}
\hline Interval Skor & Kategori \\
\hline$X>71,4$ & Sangat Baik \\
$57,8<X \leq 71,4$ & Baik \\
$44,2<X \leq 57,8$ & Cukup \\
$30,6<X \leq 44,2$ & Kurang \\
$X \leq 30,6$ & Sangat Kurang \\
\hline
\end{tabular}

Kualitas perangkat pembelajaran yang dikembangkan dianggap memenuhi kualitas kepraktisan jika skor penilaian guru minimal dalam kategori baik. Sedangkan pada lembar penilaian kepraktisan oleh siswa terdapat 10 butir aspek yang dinilai, dengan skor tertinggi untuk masing-masing aspek adalah 5 dan skor terendah adalah 1 . Dengan menggunakan rumus konversi pada Tabel 1 diperoleh kategori skor penilaian kepraktisan oleh siswa seperti pada Tabel 5.

Tabel 5. Kategori Skor Penilaian Kepraktisan oleh Siswa

\begin{tabular}{ll}
\hline Interval Skor & Kategori \\
\hline$X>42$ & Sangat Baik \\
$34<X \leq 42$ & Baik \\
$26<X \leq 34$ & Cukup \\
$18<X \leq 26$ & Kurang \\
$X \leq 18$ & Sangat Kurang \\
\hline
\end{tabular}

Perangkat pembelajaran yang dikembangkan dikatakan praktis jika jumlah rata-rata penilaian siswa minimal dalam kategori baik.

Secara umum, perangkat pembelajaran yang dikembangkan dikatakan praktis jika hasil persentase keterlaksanaan kegiatan pembelajaran $\geq 90 \%$, penilaian guru terhadap perang-kat pembelajaran berada pada kategori minimal baik dan penilaian siswa terhadap LKS berada pada kategori minimal baik. 
Data keefektifan diperoleh dari hasil tes kemampuan berpikir kritis siswa dan angket rasa ingin tahu siswa. Skor yang diperoleh pada tes kemampuan berpikir kritis akan dikonversi sehingga menjadi nilai dengan rentang antara 0 sampai dengan 100 . Rata-rata nilai tersebut selanjutnya dibandingkan dengan kriteria ketuntasan minimal (KKM) yang ditetapkan yaitu 75. Langkah analisis angket rasa ingin tahu siswa adalah menentukan skor total yang diperoleh masing-masing siswa. Selanjutnya menentukan skor total keseluruhan yang diperoleh dan mengonversikan data kuantitatif menjadi data kualitatif.

Selanjutnya akan dihitung persentase ketuntasan belajar siswa menggunakan rumus sebagai berikut.

Keterangan:

$$
t=\frac{\sum N t}{\sum N} \times 100 \%
$$

$t \quad=$ persentase ketuntasan belajar (\%)

$\sum N t$ = banyaknya siswa yang tuntas

$\sum N$ = banyaknya siswa yang mengikuti tes

Dengan demikian interval yang digunakan untuk menentukan kategori keefektifan ditinjau dari persentase ketuntasan dapat dilihat pada Tabel 6.

Tabel 6. Kategori Skor Penilaian Keefektifan ditinjau dari Kemampuan Berpikir Kritis

\begin{tabular}{ll}
\hline Interval Skor & Kategori \\
\hline$X>80$ & Sangat Tinggi \\
$60<X \leq 80$ & Tinggi \\
$40<X \leq 60$ & Cukup \\
$20<X \leq 40$ & Kurang \\
$X \leq 20$ & Sangat Kurang \\
\hline
\end{tabular}

Perangkat pembelajaran dikatakan efektif ditinjau dari kemampuan berpikir kritis siswa jika minimal persentase ketuntasan siswa yang dicapai memenuhi kategori tinggi. Sedangkan untuk menentukan kategori keefektifan ditinjau dari hasil angket rasa ingin tahu dapat dilihat pada Tabel 7.

Tabel 7. Kategori Skor Penilaian Keefektifan ditinjau dari Rasa Ingin Tahu

\begin{tabular}{ll}
\hline Interval Skor & Kategori \\
\hline$X>126$ & Sangat Tinggi \\
$102<X \leq 126$ & Tinggi \\
$78<X \leq 102$ & Cukup \\
$54<X \leq 78$ & Kurang \\
$X \leq 54$ & Sangat Kurang \\
\hline
\end{tabular}

Perangkat pembelajaran berupa RPP dan LKS yang dikembangkan dikatakan efektif apabila rata-rata skor angket rasa ingin tahu yang diperoleh berada pada kategori minimal tinggi.

\section{HASIL DAN PEMBAHASAN}

Prosedur pengembangan perangkat pembelajaran matematika SMA kelas XI MIA semester genap menggunakan pendekatan inquiry berorientasi pada kemampuan berpikir kritis dan rasa ingin tahu siswa dalam penelitian ini menggunakan model ADDIE. Penjelasan mengenai masing-masing tahapan pengembangan dan deskripsi hasil penelitian akan dibahas sebagai berikut.

\section{Tahap Analisis (Analysis)}

Salah satu masalah yang terdapat di sekolah saat ini adalah terbatasnya perangkat pembelajaran, khususnya perangkat pembelajaran matematika yang memfasilitasi siswa menemukan konsep secara mandiri. Penggunaan LKS di sekolah biasanya diperoleh dari penerbit yang berisi latihan soal. Selain itu, penggunaan metode ceramah masih mendominasi dalam pembelajaran matematika. guru telah menyusun RPP dan LKS untuk digunakan selama proses pembelajaran. Meski begitu, LKS yang disusun guru lebih banyak berisi latihan soal saja. LKS yang berisi latihan soal belum mampu memenuhi kebutuhan siswa dalam menemukan konsep-konsep matematika. Bahkan 
kadang kala pada proses pembelajaran, siswa tidak mengonstruk pengetahuannya sendiri dengan mengerjakan LKS, tetapi langsung diberi tahu rumus-rumusnya oleh guru. Guru belum memberikan kepercayaan terhadap siswa untuk menemukan konsep-konsep baru dengan pola pikir dan cara mereka sendiri sehingga siswa menjadi pasif dan kurang berkembang. Siswa tidak dilatih berpikir sendiri dan hanya menerima semua informasi dan pengetahuan dari guru. Beberapa siswa terlihat aktif dalam menjawab pertanyaan yang diberikan guru. Namun yang lainnya terutama yang duduk di bangku belakang memilih diam atau bahkan mengobrol dengan teman sebangkunya. Keadaan ini mengindikasi bahwa siswa tidak begitu tertarik dalam belajar matematika dan rasa ingin tahunya rendah. Akibatnya kemampuan berpikir siswa, terutama kemampuan berpikir kritisnya menjadi kurang berkembang.

Berdasarkan tingkat perkembangan intelektual Piaget, siswa SMA berada pada tingkat formal dimana anak dapat berpikir abstrak. Karakteristik penting dalam tahapan ini menurut Nurgiyantoro (2005, p.202) adalah: (1) anak sudah dapat berpikir secara ilmiah, berpikir teoritis, berargumentasi dan menguji hipotesis yang mengutamakan kemampuan berpikir, (2) anak sudah mampu memecahkan masalah secara logis dengan melibatkan berbagai masalah yang terkait. Sehingga perlu disusun suatu perangkat yang mampu memfasilitasi siswa dalam mengembangkan pola pikir. Perangkat yang menyajikan tidak hanya rumus dan latihan soal, namun bagaimana penemuan suatu konsep melalui aktivitas penemuan.

\section{Tahap Perencanaan (Design)}

Tahap desain atau perancangan merupakan tahapan selanjutnya setelah analisis kebutuhan, karakteristik siswa dan analisis materi dilakukan. Tahapan ini berisi kegiatan penyusunan perangkat pembelajaran yang menggunakan pendekatan inquiry berupa RPP dan LKS serta instrumen tes kemampuan berpikir kritis dan angket rasa ingin tahu siswa. Hasil dari tahap desain untuk RPP yang menggunakan pendekatan inquiry terdiri dari RPP untuk sembilan pertemuan dan berisi beberapa komponen seperti yang dijabarkan dalam Permendikbud Nomor 103 Tahun 2014 tentang Standar Proses (Kemendikbud, 2014b). Rumusan KD pada LKS berdasarkan Permendikbud Nomor 59 tahun 2014 tentang Kurikulum 2013 SMA/MA (Kemendikbud, 2014a). Penyusunan materi berupa kegiatan penemuan konsep atau rumus pada materi pada kelas XI semester genap.

\section{Tahap Pengembangan (Development)}

Hasil dari tahap pengembangan produk berupa RPP dan LKS. RPP dan LKS hasil dari tahap pengembangan ini kemudian divalidasi oleh ahli dan dilakukan revisi sesuai dengan masukan dari validator. Kategori kevalidan perangkat pembelajaran dilihat dari setiap aspeknya. Kategori kevalidan perangkat pembelajaran untuk setiap aspek dapat dilihat pada Tabel 8 .

Tabel 8. Rekapitulasi Penilaian Kevalidan RPP

\begin{tabular}{lll}
\hline Aspek yang dinilai & Rerata Skor & Kategori \\
\hline Identitas mata pelajaran & 10 & Sangat Baik \\
Rumusan indikator dan tujuan & 18,33 & Sangat Baik \\
Kesesuaian materi & 25,67 & Sangat Baik \\
Pendekatan pembelajaran & 29 & Baik \\
Kegiatan pembelajaran & 39,67 & Sangat Baik \\
Kesesuaian media dan sumber pembelajaran & 12,33 & Sangat Baik \\
Penilaian hasil belajar & 17,33 & Sangat Baik \\
Penggunaan bahasa & 18,33 & Sangat Baik \\
\hline
\end{tabular}

Selanjutnya hasil penilaian untuk RPP dari masing-masing validator secara rinci, sebagaimana disajikan pada Tabel 9. Hasil validasi yang tertera pada Tabel 9 menunjukkan bahwa RPP yang dikembangkan telah memenuhi kategori sangat baik.

Sama halnya dengan penilaian kevalidan untuk RPP, pada LKS juga dilakukan berdasarkan beberapa aspek. Hasil analisis untuk kevalidan LKS untuk setiap aspeknya dapat dilihat pada Tabel 10. 
Tabel 9. Penilaian RPP oleh Validator

\begin{tabular}{lll}
\hline Validator & Total Skor & Kategori \\
\hline I & 166 & Sangat Baik \\
II & 170 & Sangat Baik \\
III & 176 & Sangat Baik \\
\hline Rata-rata & 170,67 & Sangat Baik \\
\hline
\end{tabular}

Tabel 10. Rekapitulasi Penilaian Kevalidan LKS

\begin{tabular}{lll}
\hline Aspek yang dinilai & Rerata Skor & Kategori \\
\hline Kesesuaian dengan pendekatan Inquiry & 21,67 & Sangat Baik \\
Kesesuaian dengan kemampuan berpikir kritis & 12 & Sangat Baik \\
Kesesuaian dengan rasa ingin tahu siswa & 8,67 & Sangat Baik \\
Kesesuaian isi dan materi & 21 & Baik \\
Pengaturan tata letak LKS & 14,33 & Sangat Baik \\
Kesesuaian dengan komponen kebahasaan & 18,67 & Sangat Baik \\
Kesesuaian komponen penyajian & 17 & Sangat Baik \\
Manfaat atau kegunaan LKS & 12,67 & Sangat Baik \\
\hline
\end{tabular}

Sedangkan rekapitulasi hasil validasi dari ketiga validator untuk LKS dapat dilihat pada Tabel 11.

Tabel 11. Penilaian LKS oleh Validator

\begin{tabular}{lll}
\hline Validator & Total Skor & Kategori \\
\hline I & 119 & Baik \\
II & 130 & Sangat Baik \\
III & 129 & Sangat Baik \\
\hline Rata-rata & 126 & Baik \\
\hline
\end{tabular}

Hasil validasi yang tertera pada Tabel 11 menunjukkan bahwa LKS yang dikembangkan telah memenuhi kategori baik. Hal ini menunjukkan bahwa kualitas perangkat yang dikembangkan berupa RPP dan LKS menggunakan pendekatan inquiry dianggap valid sehingga layak untuk diuji cobakan di lapangan.

\section{Tahap Implementasi (Implementation)}

Hasil observasi keterlaksanaan, hasil penilaian guru, hasil penilaian siswa, hasil tes kemampuan berpikir kritis dan hasil angket rasa ingin tahu siswa merupakan hasil pada tahap implementasi. Data hasil observasi keterlaksanaan pembelajaran, penilaian guru dan penilaian siswa digunakan untuk mengetahui kepraktisan perangkat pembelajaran yang dikembangkan. Sedangkan hasil tes kemampuan berpikir kritis dan angket rasa ingin tahu siswa digunakan untuk mengetahui keefektifan perangkat pembelajaran berupa RPP dan LKS.

\section{Tahap Evaluasi (Evaluation)}

Hasil dari tahap evaluasi adalah hasil analisis kepraktisan dan keefektifan perangkat pembelajaran yang dikembangkan, serta hasil akhir perangkat pembelajaran berupa RPP dan LKS. Analisis data observasi keterlaksanaan pembelajaran ini dilakukan untuk mengetahui keterlaksanaan langkah-langkah pembelajaran dengan menggunakan pendekatan inquiry dan disusun berdasarkan RPP yang telah dikembangkan. Selama proses pembelajaran berlangsung, lembar observasi diisi oleh observer yang dalam penelitian ini adalah peneliti dan guru mata pelajaran. Data hasil observasi disajikan dalam Tabel 12. Berdasarkan Tabel 12, dapat dilihat bahwa keterlaksanaan pembelajaran untuk setiap pertemuan berada pada kategori sangat baik. Lembar analisis kepraktisan oleh guru diberikan setelah proses uji coba selesai dilakukan untuk menilai perangkat pembelajaran yang digunakan. Kepraktisan berdasarkan hasil penilaian guru disajikan dalam Tabel 13. Berdasarkan hasil penilaian kepraktisan oleh guru menunjukkan bahwa perangkat pembelajaran yang dikembangkan telah praktis dengan kategori sangat baik. 
PYTHAGORAS: Jurnal Pendidikan Matematika, 14 (1), 2019 - 65

Alfizah Ayu Indria Sari, Dhoriva Urwatul Wutsqa

Tabel 12. Hasil Observasi Keterlaksanaan Pembelajaran

\begin{tabular}{lll}
\hline Pertemuan ke- & Persentase & Kategori \\
\hline 1 & $85 \%$ & Sangat Baik \\
2 & $90 \%$ & Sangat Baik \\
3 & $90 \%$ & Sangat Baik \\
4 & $95 \%$ & Sangat Baik \\
5 & $100 \%$ & Sangat Baik \\
6 & $100 \%$ & Sangat Baik \\
7 & $100 \%$ & Sangat Baik \\
8 & $95 \%$ & Sangat Baik \\
9 & $95 \%$ & Sangat Baik \\
\hline Rata-rata & $94 \%$ & Sangat Baik \\
\hline
\end{tabular}

Tabel 13. Rekapitulasi Hasil Penilaian Kepraktisan oleh Guru

\begin{tabular}{lll}
\hline Perangkat & Skor & Kategori \\
\hline RPP & 35 & Sangat Baik \\
LKS & 41 & Sangat Baik \\
\hline Total & 76 & Sangat Baik \\
\hline
\end{tabular}

Lembar analisis kepraktisan oleh siswa diberikan setelah proses uji coba selesai dilakukan. Siswa diminta mengisi lembar penilaian mengenai LKS yang telah digunakan selama masa uji coba. Dari 32 siswa yang memberi penilaian, 31\% menyatakan bahwa LKS yang mereka gunakan masuk pada kategori sangat baik, sedangkan sisanya sebesar $69 \%$ siswa memberi penilaian baik. Dari hasil penilaian yang diberikan siswa, rata-rata penilaian siswa terhadap LKS adalah 41,44. Nilai rata-rata yang dihasilkan ini masuk pada kategori baik. Hasil analisis kepraktisan berdasarkan keterlaksanaan pembelajaran, penilaian guru, dan penilaian siswa menunjukkan bahwa perangkat pembelajaran telah masuk pada kategori praktis.

Tes kemampuan berpikir kritis siswa diberikan pada akhir bab aturan pencacahan dan peluang serta bab lingkaran. Keefektifan perangkat pembelajaran berdasarkan kemampuan berpikir kritis yang meliputi dua materi tersebut disajikan pada Tabel 14.

Tabel 14. Hasil Tes Kemampuan Berpikir Kritis

\begin{tabular}{lll}
\hline \multirow{2}{*}{ Deskripsi } & Materi & \\
\cline { 2 - 3 } & $\begin{array}{l}\text { Aturan Pencacahan } \\
\text { dan Peluang }\end{array}$ & Lingkaran \\
\hline Rata-rata & 75,47 & 77,03 \\
Nilai tertinggi & 90 & 100 \\
Nilai terendah & 55 & 60 \\
Jumlah siswa tuntas & 24 & 26 \\
Persentase ketuntasan & $75 \%$ & $81 \%$ \\
\hline Rata-rata persentase ketuntasan & $78 \%$ & \\
\hline
\end{tabular}

Berdasarkan Tabel 14 diketahui bahwa ke-tuntasan hasil tes kemampuan berpikir siswa sebesar $75 \%$ untuk materi aturan pencacahan dan peluang serta sebesar $81 \%$ untuk materi lingkaran. Hasil analisis ini menunjukkan bahwa perangkat pembelajaran telah masuk pada kategori efektif.

Penilaian kualitas keefektifan selain dari tes yang mengukur rasa ingin tahu siswa juga berdasarkan pada hasil angket rasa ingin tahu siswa. Angket diberikan sebelum dan setelah diberikan materi pelajaran selama pelaksanaan uji coba berlangsung. Hasil angket ditunjukkan pada Tabel 15. Berdasarkan Tabel 15, terdapat $9 \%$ siswa atau sekitar tiga orang siswa yang memiliki rasa ingin tahu yang sangat tinggi. 23 orang siswa atau sekitar $72 \%$ siswa berada pada kategori memiliki rasa ingin tahu yang tinggi. Sedangkan sisanya sebanyak enam orang siswa atau sekitar $19 \%$ siswa memiliki rasa ingin tahu sedang. Hasil analisis ini menunjukkan bahwa perangkat pembelajaran telah masuk pada kategori efektif. 
Tabel 15. Klasifikasi Hasil Angket Rasa Ingin Tahu Siswa

\begin{tabular}{lll}
\hline Interval Skor & Kriteria & Persentase \\
\hline$X>126$ & Sangat Tinggi & $9 \%$ \\
$102<X \leq 126$ & Tinggi & $72 \%$ \\
$78<X \leq 102$ & Sedang & $19 \%$ \\
$54<X \leq 78$ & Rendah & - \\
$X \leq 54$ & Sangat Rendah & - \\
\hline Rata-rata & & 107,43 \\
\hline Kriteria & & Tinggi \\
\hline
\end{tabular}

\section{Revisi Produk Pengembangan}

Revisi produk pengembangan perangkat pembelajaran menggunakan pendekatan inquiry dilakukan sebanyak dua kali. Revisi pertama dilakukan berdasarkan saran yang diberikan oleh dosen pembimbing dan validator. Revisi yang dilakukan mengenai RPP dan LKS yang dikembangkan menggunakan pendekatan inquiry secara ringkas disajikan pada Tabel 16.

Tabel 16. Saran/Masukan Hasil Validasi

\begin{tabular}{ll}
\hline Komponen & Saran/ Masukan \\
\hline RPP & Menuliskan banyaknya pertemuan, membuat KD dan indikator ketercapaian dalam bentuk \\
& tabel, materi pelajaran dibuat untuk setiap pertemuan, langkah pembelajaran inquiry lebih \\
& diperjelas dalam penjabaran kegiatan pada RPP, mencantumkan sumber belajar yang \\
& menjadi rujukan. \\
& Mengganti masalah pada LKS menjadi masalah kontekstual, memberikan arahan langkah \\
LKS & mengerjaan LKS, memperbaiki redaksional penulisan, konsisten dalam penulisan, dan \\
& memberi arahan dalam kolom kesimpulan.
\end{tabular}

Setelah perangkat pembelajaran yang dikembangkan diujicobakan, masih ditemukan beberapa kekurangan sehingga perlu dilakukan perbaikan. Revisi yang dilakukan setelah uji coba yaitu dapat dilihat pada Tabel 17.

Tabel 17. Revisi Setelah Uji Coba

\begin{tabular}{ll}
\hline Komponen & Bagian yang direvisi \\
\hline RPP & RPP yang dibuat dijadikan untuk satu pertemuan. \\
LKS & Menyediakan garis bantu pada bidang Cartesius. \\
\hline
\end{tabular}

\section{Kajian Produk Akhir}

Berdasarkan tahapan yang telah dilakukan, dapat diketahui kualitas pembelajaran yang dikembangkan. Sesuai dengan pendapat Nieveen (1999, p.126), produk pengembangan yang berkualitas harus memenuhi kriteria kevalidan, kepraktisan dan keefektifan. Sehingga berdasarkan hasil validasi ahli dan uji coba lapangan yang telah dilakukan, diperoleh bahwa perangkat pembelajaran yang dikembangkan telah memenuhi kriteria valid, praktis dan efektif.

Penilaian yang dilakukan oleh validator untuk perangkat pembelajaran yang menggunakan pendekatan inquiry berupa RPP yang telah memenuhi kriteria valid dan LKS dengan kategori sangat baik dan kriteria valid dengan kategori baik. Perangkat pembelajaran juga telah direvisi berdasarkan masukan atau saran dari validator sehingga layak untuk digunakan. Perangkat pembelajaran berupa RPP dan LKS nilai valid karena dalam pengembangannya berdasarkan pada teori-teori yang relevan. Meskipun sudah dinyatakan valid dengan kategori baik, tetapi masih ada beberapa aspek yang hanya dalam kategori baik. Pada RPP, terdapat satu aspek yang berkategori baik yaitu pendekatan pembelajaran. Pada LKS, ada satu aspek yang berkategori baik, yaitu aspek kesesuaian isi dan materi.

Kriteria kepraktisan perangkat pembelajaran digunakan untuk menjawab pertanyaan "apakah perangkat pembelajaran yang dikembangkan dapat dengan mudah digunakan oleh guru dan siswa dalam pembelajaran di kelas". Pada penelitian ini, kepraktisan perangkat pembelajaran yang dikembangkan berdasarkan pada hasil observasi keterlaksanaan pembelajaran, penilaian guru setelah melaksanakan pembelajaran menggunakan 
perangkat pembelajaran yang dikembangkan, serta penilaian siswa yang menggunakan perangkat pembelajaran berupa LKS. Hasil observasi keterlaksanaan pembelajaran menunjukkan bahwa tingkat keterlaksanaan pembelajaran berada pada kategori sangat baik. Namun, jika dilihat dari persentase keterlaksanaan pembelajaran untuk setiap kegiatan pembelajaran, masih ada dua kegiatan yang kurang maksimal. Kegiatan tersebut adalah "memotivasi siswa dengan memberikan contoh aplikasi materi yang dipelajari dalam kehidupan sehari-hari" dan "memberi kesempatan bertanya kepada siswa, memberikan komentar dan saran terhadap hasil presentasi". Kegiatan pertama sulit dilakukan terutama untuk materi lingkaran mengenai persamaan garis singgung lingkaran. Kegiatan berikutnya terlewatkan untuk dilaksanakan, karena guru tidak memberikan kesempatan kepada siswa untuk bertanya.

Setelah uji coba lapangan, diperoleh hasil penilaian guru setelah melaksanakan pembelajaran menggunakan perangkat pembelajaran yang dikembangkan termasuk pada kategori sangat baik. Perangkat pembelajaran ini juga telah direvisi sesuai dengan saran yang telah diberikan guru. Untuk lebih jelasnya, revisi dapat dilihat pada bagian revisi produk setelah uji coba lapangan. Selanjutnya, hasil penilaian siswa setelah mengikuti pembelajaran menggunakan perangkat pembelajaran yang dikembangkan, $31 \%$ berada pada kategori sangat baik, dan sisanya berada pada kategori baik. Berdasarkan hasil observasi keterlaksanaan pembelajaran, penilaian guru, dan penilaian siswa, maka dapat disimpulkan bahwa perangkat pembelajaran yang dikembangkan telah memenuhi kriteria praktis.

Uji coba lapangan yang telah dilakukan menunjukkan bahwa perangkat pembelajaran menggunakan pendekatan inquiry yang dikembangkan telah memenuhi kriteria efektif. Hal ini dapat dilihat dari tes kemampuan berpikir kritis dan hasil angket rasa ingin tahu siswa. Hasil tes kemampuan berpikir kritis siswa telah menunjukkan bahwa lebih dari $60 \%$ siswa telah berada pada kategori tinggi. Sedangkan hasil angket rasa ingin tahu siswa menunjukkan bahwa total skor angket sesudah digunakannya perangkat yang dikembangkan lebih dari total skor angket sebelum serta lebih dari $60 \%$ siswa pada kategori minimal tinggi.

Guru mengawali pembelajaran dengan memberikan motivasi dan apersepsi mengenai materi yang akan dipelajari. Siswa dalam proses pembelajaran menggunakan perangkat pembelajaran yang dikembangkan menggunakan pendekatan inquiry. Efektifnya perangkat pembelajaran menggunakan pendekatan inquiry ini karena dalam pembelajaran matematika dapat memfasilitasi rasa ingin tahu yang dimiliki siswa sehingga pembelajaran menjadi lebih bermakna dan menyenangkan. Pada awal pembelajaran siswa diberi kesempatan untuk mengamati pendahuluan pada LKS yang berupa pengetahuan tambahan atau permasalahan yang terkait dengan topik yang akan dipelajari. Sebagai contoh, permasalahan yang dimaksud dapat dilihat pada Gambar 1 .

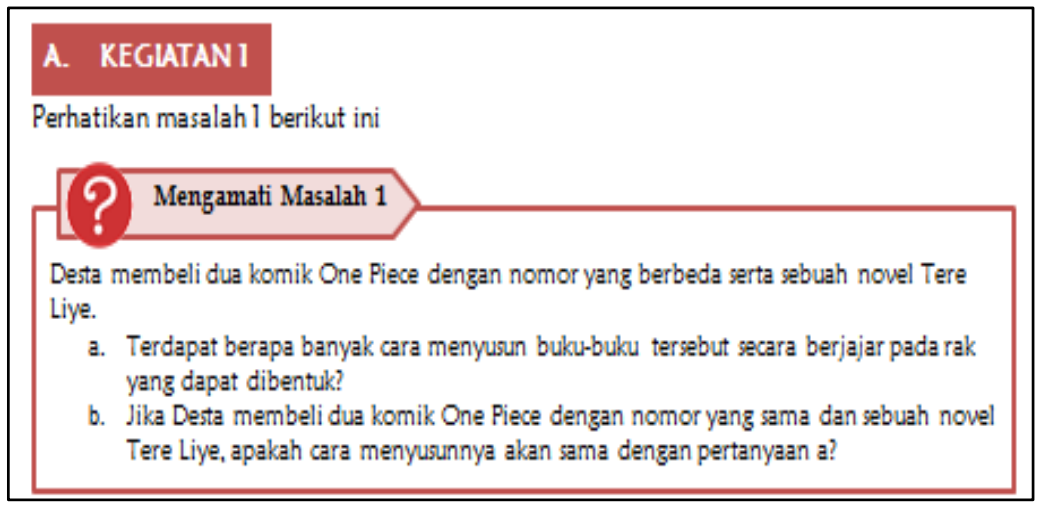

Gambar 1. Contoh Masalah yang Disajikan dalam LKS

LKS dirancang untuk menemukan konsep tentang materi yang dipelajari. Hal tersebut dapat memfasilitasi dan menimbulkan keingintahuan siswa untuk mempelajari topik matematika. Rasa ingin tahu memiliki pengaruh yang cukup besar dalam menjembatani siswa untuk belajar. Hal ini sejalan dengan pendapat Bundu (2006, p.41) bahwa rasa ingin tahu mendorong siswa dalam penemuan sesuatu yang baru, salah satunya melalui kemampuan berpikir kritis.

Pada kegiatan selanjutnya, siswa dapat berdiskusi kelompok secara intensif sehingga mereka akan saling bertanya, menjawab, memberikan ide, mengkritisi, dan mengoreksi konsep yang muncul dalam diskusi. Dengan demikian akan memantapkan pemahaman siswa terhadap konsep yang sedang dipelajari dan juga terhadap penyelesaian masalah matematika. Selain itu, kegiatan ini juga memungkinkan siswa untuk mengumpulkan 
informasi, melakukan penyelidikan, dan membuat kesimpulan. Semua kegiatan tersebut akan membuat siswa aktif mengikuti pembelajaran. Hal ini sesuai dengan Minner et al. $(2009$, p.1) yang menyebutkan bahwa pembelajaran dengan pendekatan inquiry dapat mengaktifkan siswa ke dalam proses pembelajaran melalui penyelidikan ilmiah yang dapat meningkatkan pemahanan konsep.

Pembelajaran dengan pendekatan inquiry juga mampu mengembangkan kemampuan berpikir kritis siswa. Hal tersebut didukung oleh pendapat Arp et al. (2004, p.34) yang menyatakan bahwa berpikir kritis adalah bentuk khusus dari pembelajaran inquiry sebagai cabang dari kegiatan eksplorasi. Trilling dan Fadel $(2009$, p.53) juga mengatakan bahwa berpikir kritis dan kemampuan pemecahan masalah dapat diajarkan melalui pembelajaran inquiry dan aktivitas problem-solving. Kemampuan yang dibangun ini lebih efektif melalui pembelajaran bermakna dengan pertanyaan dan masalah yang menarik, sehingga pembelajaran dengan pendekatan inquiry dapat membuat siswa menjadi aktif dan meningkatkan kemampuan berpikir kritis siswa.

Pada LKS yang menerapkan pendekatan inquiry juga terdapat latihan soal. Dengan adanya latihan soal dalam bentuk uraian, maka siswa perlu berpikir secara logis untuk menerapkan konsep yang telah didapatkan dan mencari solusi dari permasalahan matematika. Latihan soal yang ada pada LKS ini merupakan bentuk soal yang memfasilitasi kemampuan berpikir kritis siswa. Sehingga benar kiranya pendapat dari Moore (2009, p.380) yang menyatakan bahwa kemampuan berpikir kritis dapat dikembangkan dalam setiap diri siswa, dimana dalam proses untuk mengembangkannya diperlukan pembelajaran yang melibatkan proses pemahaman.

Di akhir pembelajaran matematika, siswa dibimbing untuk membuat kesimpulan dari materi yang dipelajari. Selain itu, guru juga mengajak siswa untuk melakukan refleksi tentang pembelajaran yang telah dilakukan. Guru mengajak siswa untuk melakukan refleksi dengan menanyakan beberapa pertanyaan. Tidak lupa guru juga memberikan tugas sebagai pekerjaan rumah. Efektivitas pembelajaran matematika menggunakan pendekatan inquiry berorientasi pada kemampuan berpikir kritis sejalan dengan studi yang dilakukan Friesen dan Scott (2013) menyebutkan dalam review-nya mengenai Inquiry-Based Learning, pendekatan inquiry atau pembelajaran inquiry memberi dampak positif bagi kemampuan siswa dalam memahami konsep dan prosedur. Inquiry juga menciptakan suasana belajar yang lebih menarik.

\section{SIMPULAN}

Perangkat pembelajaran dengan pendekatan Inquiry yang berorientasi pada kemampuan berpikir kritis dan rasa ingin tahu siswa SMA kelas XI semester genap yang terdiri dari RPP dan LKS berturut-turut telah memenuhi kriteria valid yang dibuktikan dari rata-rata skor validasi untuk RPP yaitu 170,67 (sangat baik) dan rata-rata skor validasi terhadap LKS yaitu 126 (baik). Perangkat pembelajaran dengan pendekatan Inquiry yang berorientasi pada kemampuan berpikir kritis dan rasa ingin tahu siswa memenuhi kriteria praktis yang dibuktikan berdasarkan total skor penilaian guru yaitu, 76 (sangat baik), rata-rata skor hasil penilaian siswa yaitu 41,44 (baik), dan rata-rata persentase keterlaksanaan pembelajaran yaitu $94 \%$. Perangkat pembelajaran yang dikembangkan memenuhi kriteria efektif ditinjau dari kemampuan berpikir kritis dan rasa ingin tahu siswa yang dibuktikan dari rata-rata persentase banyaknya siswa yang tuntas pada tes kemampuan berpikir kritis siswa adalah $78 \%$ dan persentase banyaknya siswa yang mencapai kategori rasa ingin tahu minimal tinggi sebesar $72 \%$.

Beberapa saran berdasarkan temuan penelitian ini meliputi beberapa hal. Pertama, pembelajaran akan berjalan efektif jika perangkat pembelajaran dipersiapkan dan dikembangkan sendiri oleh guru. Hal ini dikarenakan guru yang lebih mengetahui karakteristik dan kebutuhan siswa dalam proses pembelajaran. Kedua, guru hendaknya memilih masalah nyata dalam kehidupan sehari-hari yang mudah dipahami oleh siswa. Subjek uji coba hanya menggunakan satu kelas dan satu sekolah saja. Oleh karena itu disarankan untuk dilakukan penelitian serupa dengan menggunakan populasi yang lebih besar. Ketiga, perlu adanya tindak lanjut dari peneliti lain dalam mengembangkan perangkat pembelajaran pada materi yang lain sehingga perangkat pembelajaran dengan pendekatan inquiry yang berorientasi pada kemampuan berpikir kritis dan rasa ingin tahu siswa pada materi yang lain akan lebih banyak tersedia.

\section{DAFTAR PUSTAKA}

Abdi, A. (2014). The effect of inquiry-based learning method on students' academic achievement in science course. Universal Journal of Educatinal Research, 2(1), 37-41. doi: https://doi.org/10.13189/ujer.2014.020104 
Aizikovitsh-Udi, E., \& Cheng, D. (2015). Developing critical thinking skill from dispositions to abilities: Mathematics education from early childhood to high school. Creative Education, 6(1), 455-462. http://dx.doi.org/10.4236/ ce.2015.64045

Anggraeni, N. W., Ristiati, N. P., \& Widiyanti, P. M. (2013). Implementasi strategi pembelajaran inkuiri terhadap kemampuan berpikir kritis dan pemahaman konsep IPA siswa SMP. Jurnal Pendidikan dan Pembelajaran IPA Indonesia, 3(1), 1-11. Retrieved from http://oldpasca.undiksha.ac.id/e-journal/index.php/jurnal_ipa/ article/view/752

Arp, L., Woodard, B. S., \& Hansley, R. B. (2004). Curiosity and creativity as attributes of information literacy. Reference \& User Services Quarterly, 44(1), 31-36.

Asgharheidari, F., \& Tahriri, A. (2015). A survey of EFL teachers' attitudes towards critical thinking instruction. Journal of Language Teaching and Research, 6(2), 388-396. doi: http://dx.doi.org/10.17507/jttr.0602.20

Astika, I. K. U., Suma, I. K., \& Suastra, I. W. (2013). Pengaruh model pembelajaran berbasis masalah terhadap sikap ilmiah dan keterampilan berpikir. Jurnal Pendidikan dan Pembelajaran IPA Indonesia, 3(1), 1-10. Retrieved from http://oldpasca.undiksha.ac.id/e-journal/index.php/jurnal_ipa/article/view/851

Bayer, B. K. (1990). What philosophy offers to teaching thinking [Versi elektronik]. Educational Leadership, 2(1), 5560. Retrieved from http://www.ascd.org/ASCD/pdf/journals/ed_lead/el_199002_beyer.pdf

Bundu, P. (2006). Penilaian keterampilan proses dan sikap ilmiah dalam pembelajaran sains SD. Jakarta: Depdiknas.

Chiappetta, E. L., \& Collate, A.T. (1994). Science instruction in the middle and secondary schools thrid edition. New York, NY: Macmillan Publishing Company.

Chambers, P. (2008). Teaching mathematics. London, UK: Sage Publications.

Conklin, W. (2012). Higher order thinking skill to develop $21^{\text {st }}$ century learners. Huntington Beach, CA: Shell Education Publishing.

Damanik, D. P., \& Bukit, N. (2013). Analisis kemampuan berpikir kritis dan sikap ilmiah pada pembelajaran fisika menggunakan model pembelajaran inquiry training dan direct instruction. Jurnal Online Pendidikan Fisika, 2(1), 16-24. doi: https://doi.org/10.22611/jpf.v2i1.4333

Facione, P. A. (1990). Critical thinking: A statement of expert consensus for purposes of education assessment and instruction. Millbrae, CA: California Academic Press.

Fatmawati, H., Mardiyana, M., \& Triyanto, T. (2014). Analisis berpikir kritis siswa dalam pemecahan masalah matematika berdasarkan polya pada pokok bahasan persamaan kuadrat. Jurnal Elektronik Pembelajaran $\begin{array}{llll}\text { Matematika, 2(9), } & \text { 899-910. } & \text { Retrieved }\end{array}$ https://jurnal.fkip.uns.ac.id/index.php/s2math/article/view/4830

Firdaus, F., Kailani, I., Bakar, M. N. B., \& Bakry, B. (2015). Developing critical thinking skills of students in mathematics learning. Journal of Education and Learning, 9(3), 226-236. Retrieved from https://media.neliti.com/media/publications/72687-EN-developing-critical-thinking-skills-of-s.pdf

Friesen, S., \& Scott, D. (2013). Inquiry based learning: A review of the research literature (online). Retrieved from http://goo.gl/IIJmDn

Freeley, A. (2001). Critical thinking: An introduction. Cambridge, UK: University Press Cambridge.

Jarett, D. (1997). Inquiry strategies for science and mathematics learning: It's just good teaching. New York, NY: Northwest Regional Educational Laboratory.

Kemendikbud. (2013). Peraturan Menteri Pendidikan dan Kebudayaan Nomor 65 Tahun 2013, tentang Standar Proses.

Kemendikbud. (2014a). Peraturan Menteri Pendidikan dan Kebudayaan Nomor 59 Tahun 2013 tentang Kurikulum 2013 Sekolah Menengah Atas/Madrasah Aliyah. 
Kemendikbud. (2014b). Peraturan Menteri Pendidikan dan Kebudayaan Nomor 103 Tahun 2014 tentang Pembelajaran pada Pendidikan Dasar dan Pendidikan Menegah.

Kuhlthau, C. C., Maniotes, L. K., \& Caspari A. K. (2007). Guided inquiry learning in the 21st century. London, UK : Greenwood Publishing Group.

Kunandar, K. (2013). Penilaian autentik. Jakarta: Raja Grafindo.

Llewellyn, D. (2005). Teaching high school science through inquiry. Thousand Oaks, CA: Corwin Press.

Maw, W., \& Maw, E. (1963). The differences between the scores of children with high curiosity and children withlow curiosity ona test of general information. Journal of Education Research, 57(2), 76-79. Retrieved from http://www.jstor.org/stable/27531352

McElmeel, S. L. (2002). Character education: A book guide for teachers, librarians and parents. Englewood, CO: Greenwood Publishing Group.

Minner, D. D., Levy, A. J., \& Century, J. (2009). Inquiry-based science instruction- what is it and does it matter? Results from a research synthesis years 1984 to 2002. Journal of Research in Science Teaching, 47(1), 474-496. doi: https://doi.org/10.1002/tea.20347

Moon, B., Mayes, A. S., \& Hutchinson, S. (2002). Teaching, learning and the curriculum in secondary school. New York, NY : Routledge.

Moore, K. D. (2009). Effective instructional strategies, from theory to practice. Thousand Oaks, CA: Sage Publications.

Nieveen, N. (1999). Prototype to reach product quality. In J. van den Akker, K. Gravemeijer, S. McKenney, N. Nieveen (Eds.), Design approaches and tools in education and training (pp. 125-136). Dordretch: Kluwer Academic Publisher.

Nurgiyantoro, B. 2005. Tahapan perkembangan anak dan pemilihan bacaan sastra anak. Cakrawala Pendidikan, XXIV(2), 198-216. doi: https://doi.org/10.21831/cp.v0i2.369

Renner, B. (2006). Curiosity about people: the development of a social curiosity measure in adults. Journal of Personality Assesment, 83(3), 305-316. doi: https://doi.org/10.1207/s15327752jpa8703_11

Sagala, S. (2011). Konsep dan makna pembelajaran. Bandung: Alpabeta.

Suhartini, S., \& Santoso, R. H. (2014). Pengembangan perangkat pembelajaran matematika untuk siswa SMK jurusan akuntansi di Sleman dengan pendekatan pembelajaran kontekstual. Jurnal Riset Pendidikan Matematika, 1(1), 69-76. doi: https://doi.org/10.21831/jrpm.v1i1.2665

Sumarno, S., \& Wutsqa, D. U. (2014). Pengembangan perangkat pembelajaran pada materi pokok kalkulus SMA kelas XI semester 2. Jurnal Riset Pendidikan Matematika, 1(2), 257-267. doi: https://doi.org/10.21831/jrpm.v1i2.2680

Thompson, C. (2011). Critical thinking across the curriculum: process over output. International Journal of Humanities and Social Science, 1(9), 1-7. Retrieved from https://www.ijhssnet.com/journal/index/263

Trilling, B., \& Fadel, C. (2009). 21st century skills: Learning for life in our times. San Fransisco, CA: Jossey-Bass.

Widoyoko, E. P. (2009). Evaluasi program pembelajaran. Yogyakarta: Pustaka Pelajar. 